\title{
EHMTI-0216. Primary headache among adolescents in Albania
}

\author{
J Kruja ${ }^{*}$, I Alimehmeti $^{2}$, D Dobi ${ }^{3}$, A Kuqo $^{3}$, S Mijo $^{3}$, S Grabova ${ }^{3}$, M Rakacolli $^{1}$ \\ From 4th European Headache and Migraine Trust International Congress: EHMTIC 2014 \\ Copenhagen, Denmark. 18-21 September 2014
}

\section{Aim}

To point out the prevalence of headache in adolescents.

\section{Methods}

A door-to-door survey was undertaken in Tirana. The random samples of the local population underwent a structured interview to ascertain some neurological disorders, including headache. The diagnosis was made using standard criteria for epidemiological studies and was confirmed by history, neurological examination and where available, the review of personal medical records. The prevalence ratios according to age groups with $95 \%$ confidence intervals were calculated. The 15-19 years old group is studied in details. Age adjusted study to the general population age gropus is applied.

\section{Results}

4.06\% $(\mathrm{n}=51)$ of individuals reporting headache and living in urban areas are 15-19 years old. Comparing this figure to data extracted from the national census, where the proportion of 15-19 years old in the general urban population is $8.69 \%(n=130.227)$, generates a relative risk of 0.467 for having a headache in this age group. There is an extremely statistic significance in the difference between these two proportions $(\mathrm{z}=5.83, \mathrm{p}<0.0001)$.

\section{Conclusion}

Headache is relatively uncommon in 15-19 years old individuals in Tirana, Albania

No conflict of interest.

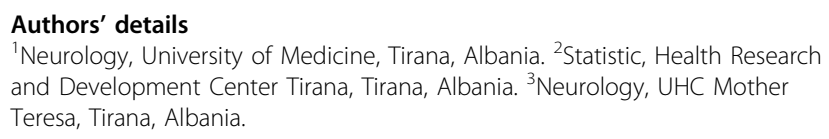

${ }^{1}$ Neurology, University of Medicine, Tirana, Albania. ${ }^{2}$ Statistic, Health Research and Development Center Tirana, Tirana, Albania. ${ }^{3}$ Neurology, UHC Mother Teresa, Tirana, Albania.

${ }^{1}$ Neurology, University of Medicine, Tirana, Albania

Full list of author information is available at the end of the article
Published: 18 September 2014

doi:10.1186/1129-2377-15-S1-B17

Cite this article as: Kruja et al.: EHMTI-0216. Primary headache among adolescents in Albania. The Journal of Headache and Pain 2014 15(Suppl 1):B17.

\section{SpringerOpen ${ }^{\odot}$}

(C) 2014 Kruja et al; licensee Springer. This is an Open Access article distributed under the terms of the Creative Commons Attribution License (http://creativecommons.org/licenses/by/2.0), which permits unrestricted use, distribution, and reproduction in any medium, provided the original work is properly cited.
Submit your manuscript to a SpringerOpen ${ }^{\circ}$ journal and benefit from:

- Convenient online submission

- Rigorous peer review

- Immediate publication on acceptance

- Open access: articles freely available online

- High visibility within the field

- Retaining the copyright to your article

Submit your next manuscript at $>$ springeropen.com 